Article

\title{
Temperature-Dependent Demographic Characteristics and Control Potential of Aphelinus asychis Reared from Sitobion avenae as a Biological Control Agent for Myzus persicae on Chili Peppers
}

\author{
Sheng Yin Wang ${ }^{1,2} \oplus$, Bo Li Wang ${ }^{3}$, Gai Lan Yan ${ }^{4}$, Yan Hong Liu ${ }^{2,5}$, Da Yu Zhang ${ }^{1}$ \\ and Tong Xian Liu ${ }^{2, *}$ \\ 1 College of Agriculture and Food Science, Zhejiang A\&F University, Hangzhou 311300, China; \\ 20160040@zafu.edu.cn (S.Y.W.); zhangdayu@zafu.edu.cn (D.Y.Z.) \\ 2 College of Plant Protection, Northwest A\&F University, Yangling 712100, China; liuyanhong1984@126.com \\ 3 College of Economic and Management, Zhejiang A\&F University, Hangzhou 311300, China; \\ zafuwlb@163.com \\ 4 Fengdong New City Administration for Market Regulation, Xi'an 710086, China; yglnafu@163.com \\ 5 College of Plant Protection, Shanxi Agricultural University, Taigu 030801, China \\ * Correspondence: txliu@nwafu.edu.cn
}

Received: 3 July 2020; Accepted: 23 July 2020; Published: 27 July 2020

\begin{abstract}
Aphelinus asychis, a polyphagous parasitoid, has been widely used as an efficient biological control agent against the aphid Myzus persicae. Aiming to evaluate the influence of temperature on the biological characteristics and control potential of $A$. asychis for $M$. persicae, we compared the life table parameters and control potential of $A$. asychis, which included the developmental time, longevity, fecundity, intrinsic rate of increase $(r)$, and finite killing rate $(\theta)$. The results showed that increasing the temperature significantly decreased the developmental time and longevity of A. asychis. The $r$ at $24\left(0.2360 \mathrm{~d}^{-1}\right)$ and $28^{\circ} \mathrm{C}\left(0.2441 \mathrm{~d}^{-1}\right)$ were significantly greater than those at $20\left(0.1848 \mathrm{~d}^{-1}\right)$ and $32{ }^{\circ} \mathrm{C}\left(0.1676 \mathrm{~d}^{-1}\right)$. The $\theta$ at $24(0.4495), 28(0.5414)$, and $32{ }^{\circ} \mathrm{C}(0.4312)$ were also significantly greater than that at $20^{\circ} \mathrm{C}(0.3140)$. The relationship between population fitness $\left(r\right.$ and $\theta$ ) and temperature followed a unary quadratic function $\left(R^{2}>0.95\right)$. The temperatures for the expected maximum intrinsic rate of increase $\left(r_{\max }\right)$ and the maximum finite killing rate $\left(\theta_{\max }\right)$ were 25.7 and $27.4{ }^{\circ} \mathrm{C}$, respectively. In conclusion, $A$. asychis could develop and produce progenies within the temperature range of $20-32{ }^{\circ} \mathrm{C}$, and its control efficiency for $M$. persicae at 24,28 , and $32{ }^{\circ} \mathrm{C}$ was greater than that at $20^{\circ} \mathrm{C}$. The most suitable temperature range for controlling $M$. persicae with A. asychis in the field might be between 25.7 and $27.4^{\circ} \mathrm{C}$.
\end{abstract}

Keywords: biological control; green peach aphid; chili pepper; leaf disc; life table

\section{Introduction}

The chili pepper (Capsicum annuum, Solanaceae) is an important vegetable and condiment planted in greenhouses and open-air fields in China [1]. The green peach aphid (Myzus persicae) is a sucking pest of more than 400 host plant species covering 40 families, including the chili pepper [2,3]. It is also an important vector of more than 100 plant viruses [2]. Its fast development and high fecundity promote the build-up of large populations within a short period, especially in greenhouse agroecosystems [4]. In the past few decades, the intensive use of chemical insecticides such as carbamate [5], pyrethroid [6], cyclodiene [7], neonicotinoid [8], and many others to control M. persicae has resulted in their development of resistance to these chemicals. Furthermore, chemical insecticides also have tremendous negative impacts on beneficial organisms and the environment [9-11]. 
Because of the critical economic damage by M. persicae to chili peppers, many biological agents, including predators and parasitoids, have been extensively studied and used, especially aphelinidae wasps [12-14]. There are 84 species in the genus Aphelinus worldwide [15,16]. Most species in this genus play important roles in the biological control of aphids and have been widely used in vegetable and fruit production in greenhouses and in the field $[17,18]$. Among them, Aphelinus asychis is a polyphagous endoparasitoid of about 40 aphid host species including M. persicae and Sitobion avenae [13,18-20], and it has been used under field and greenhouse conditions [21,22].

In biological control, banker plant systems have been extensively used to control vegetable pests, including M. persicae [12,23-25]. A typical banker plant system includes three important elements: a banker plant, alternative host, and natural enemy [12]. The cost of the winter wheat (Triticum aestivum) plant is low, and the cultivation and management techniques are relatively simple. In addition, the host plants of S. avenae are only gramineous crop and grass, including the winter wheat plant [26]. Therefore, the wheat plant and S. avenae were suitable to combine for the banker plant system in many previous studies $[13,27]$. In this research, we used the winter wheat plant $S$. avenae and A. asychis to form a banker plant system, which was a continuation of our previous study [13,14].

In this banker plant system, the alternative host and natural enemy are insects, and both are ectotherms. Their physiological functions, such as locomotion, feeding, and population fitness, are significantly affected by many environmental factors, especially temperature [28-30]. In addition, the geographical distribution and invasion range of the insects is also limited by environmental temperature [31,32]. Therefore, the influence of temperature on the control efficiency and population fitness of many natural enemies has been estimated in many previous studies, such as of Aphidius gifuensis, Encarsia Formosa, Ophraella communa, and Harmonia dimidiata [33-36].

The control efficiency of parasitoids is influenced by many factors, such as temperature, prey species, host plants, etc. [37]. The linkage of the life table, parasitism, and feeding rate showed that the host plant affected the demography and parasitic effectiveness of $A$. asychis against $M$. persicae [13]. Additionally, the population fitness of the parasitoids was affected by temperature [38,39]. However, studies on the influence of temperature on the population fitness and control efficiency of $A$. asychis parasitizing $M$. persicae on chili peppers are lacking. In order to estimate its population fitness and quantitatively assess its control efficacy, we collected and analyzed data on the life table parameters, parasitism rate, and feeding rate of $A$. asychis at four constant temperatures using the age-stage, two-sex life table. In addition, we used population projection to quantitatively predict its killing potential, which might be beneficial to increase the control efficiency of $A$. asychis by regulating the environmental temperature.

\section{Materials and Methods}

\subsection{Plant and Insect Cultures}

The chili pepper plants (var. "Ox horn") were grown in a soil mixture (peat moss: perlite $=3: 1$ ) in plastic pots $\left(10 \mathrm{~cm}\right.$ in diameter) and enclosed in nylon net cages $\left(60 \times 60 \times 60 \mathrm{~cm}^{3}\right)$. Myzus persicae were reared on chili pepper plants ( 90 days old), and A. asychis was fed on S. avenae, which fed on winter wheat plants (variety, "Xinong 979"). The winter wheat plant, the chili pepper plant, M. persicae, S. avenae, and A. asychis were reared in a phytotron (photoperiod, $14: 10 \mathrm{~h}(\mathrm{~L} / \mathrm{D})$; illumination intensity, $10,000 \pm 50 \mathrm{~lx} ; 25 \pm 0.5{ }^{\circ} \mathrm{C}$; and $70 \pm 10 \% \mathrm{RH}$ (Relative Humidity)) at Northwest A\&F University, Shaanxi, China.

\subsection{Life Table, Parasitism, and Host Feeding}

Data on fecundity, the host feeding of $A$. asychis, and its killing of aphids were obtained at 20, 24, 28, and $32{ }^{\circ} \mathrm{C}$ following the method described by Wang et al. [13]. About 100 s-instar M. persicae nymphs were reared on a circular chili pepper leaf disc in a Petri dish (3 $\mathrm{cm}$ in diameter), and water-agar $(1 \%)$ was used to keep the leaf fresh. Ten mated $A$. asychis female adults that had previously emerged from 
S. avenae were transferred into the Petri dish and removed $24 \mathrm{~h}$ later. The parasitized and healthy aphid nymphs were maintained in the phytotron at $20,24,28$, and $32{ }^{\circ} \mathrm{C}$, respectively. After seven days, 50 mummified aphids were randomly selected for each treatment and monitored daily. Emerged A. asychis female and male adults were paired. If the male parasitoid was not enough or died before the female, other male adults from the non-tested population were used. Each parasitoid pair was transferred into a new Petri dish containing the fresh chili pepper leaf and 50 s-instar M. persicae nymphs for parasitism and feeding. The developmental time, longevity, parasitism, and host feeding of $A$. asychis were recorded until all the tested parasitoids died.

According to the age-stage, two-sex life table theory, the population parameters of A. asychis were analyzed with the computer program TWOSEX-MSChart [40-42]. The data on host feeding, non-effective parasitism, and aphid killing were analyzed using the computer program CONSUMEMSChart [43,44]. Using data on the age-stage-specific fecundity $\left(f_{x j}\right)$ and age-stage-specific aphid killing rate $\left(p_{x j}\right)$ at age $x$ and stage $j$, the population growth and killing potential of $A$. asychis parasitizing second-instar M. persicae nymphs were analyzed using the computer program TIMING-MSChart [45]. The parameter definitions and formulas used in this study are presented in Table 1.

The standard errors of the population parameters, host feeding, non-effective parasitism, and aphid killing were estimated with the bootstrap technique, and the differences among the four constant temperature treatments were also analyzed using the same technique [46,47].

Table 1. Population parameter definitions and formulas used in the computer programs including TWOSEX-MSChart, CONSUME-MSChart, and TIMING-MSChart.

\begin{tabular}{|c|c|c|}
\hline Parameter & Definition & Formula \\
\hline sxj & Age-stage-specific survival rate & $s_{x j}=\frac{n_{x j}}{s_{01}}$ \\
\hline lx & Age-specific survival rate & $l_{x}=\sum_{j=1}^{\beta} s_{x j}$ \\
\hline $\mathrm{mx}$ & Age-specific fecundity & $m_{x}=\frac{\sum_{j=1}^{\beta} s_{x j} f_{x j}}{\sum_{j=1}^{\beta} s_{x j}}$ \\
\hline $\mathrm{r}$ & Intrinsic rate of increase & $\lambda=e^{r}$ \\
\hline R0 & Net reproductive rate & $R_{0}=\sum_{x=0}^{\infty} l_{x} m_{x}$ \\
\hline $\mathrm{T}$ & Mean generation time & $T=\frac{\ln \left(R_{0}\right)}{r}$ \\
\hline $\mathrm{kx}$ & Age-specific host feeding rate & $k_{x}=\frac{\sum_{j=1}^{\beta} s_{x j} c_{x j}}{\sum_{j=1}^{\beta} s_{x j}}$ \\
\hline $\mathrm{qx}$ & Age-specific net host feeding rate & $q_{x}=l_{x} k_{x}$ \\
\hline $\mathrm{C} 0$ & Net host feeding rate & $C_{0}=\sum_{x=0}^{\infty} l_{x} k_{x}$ \\
\hline$\psi$ & Stable host feeding rate & $\psi=\sum_{x=0}^{\infty} \sum_{j=1}^{p} a_{x j} c_{x j}$ \\
\hline$\omega$ & Finite host feeding rate & $\omega=\lambda \varphi$ \\
\hline$g x$ & Age-specific non-effective parasitism rate & $g_{x}=\frac{\sum_{j=1}^{\beta} s_{x j} d_{x j}}{\sum_{j=1}^{\beta} s_{x j}}$ \\
\hline hx & Age-specific net non-effective parasitism rate & $h_{x}=l_{x} g_{x}$ \\
\hline No & Net non-effective parasitism rate & $N_{0}=\sum_{x=0}^{\infty} l_{x} g_{x}$ \\
\hline$\gamma$ & Stable non-effective parasitism rate & $\gamma=\sum_{x=0}^{\infty} \sum_{j=1}^{p} a_{x j} d_{x j}$ \\
\hline$\varepsilon$ & Finite non-effective parasitism rate & $\varepsilon=\lambda \gamma$ \\
\hline$\mu x$ & Age-specific aphid killing rate & $\mu_{x}=\frac{\sum_{j=1}^{\beta} s_{x j} p_{x j}}{\sum_{j=1}^{\beta} s_{x j}}$ \\
\hline $\mathrm{wx}$ & Age-specific net aphid killing rate & $w_{x}=l_{x} u_{x}$ \\
\hline $\mathrm{ZO}$ & Net aphid killing rate & $Z_{0}=\sum_{x=0}^{\infty} l_{x} u_{x}=R_{0}+C_{0}+N_{0}$ \\
\hline$\vartheta$ & Stable aphid killing rate & $\vartheta=\sum_{x=0}^{\infty} \sum_{j=1}^{\beta} a_{x j} p_{x j}$ \\
\hline
\end{tabular}


Table 1. Cont.

\begin{tabular}{ccc}
\hline Parameter & Definition & Formula \\
\hline$\theta$ & Finite aphid killing rate & $\theta=\lambda \vartheta$ \\
$\mathrm{Qp}$ & Transformation rate & $Q_{p}=\frac{Z_{0}}{R_{0}}=\frac{R_{0}+C_{0}+N_{0}}{R_{0}}$ \\
& Population growth & $p(t)=\sum_{j=1}^{m}\left(\sum_{x=0}^{\infty} f_{x j} n_{x j, t}\right)$ \\
$\mathrm{p}(\mathrm{t})$ & Killing potential & $\mathrm{t}:$ the simulation time. m: number of life stages. \\
& nxj: number of individuals of age $\mathrm{x}$ and stage $\mathrm{j}$. \\
$\mathrm{v}(\mathrm{t})$ & $v(t)=\sum_{j=1}^{m}\left(\sum_{x=0}^{\infty} p_{x j} n_{x j, t}\right)$ \\
\hline
\end{tabular}

The age-stage-specific fecundity $\left(f_{x j}\right)$ was the number of parasitoid progeny at age $x$ and stage $j$. The age-stage-specific host feeding rate $\left(c_{x j}\right)$ was the number of aphid nymphs killed by $A$. asychis female adults at age $x$ and stage $j$ for feeding. The age-stage-specific non-effective parasitism rate $\left(d_{x j}\right)$ was the number of aphid nymphs parasitized by $A$. asychis at age $x$ and stage $j$ but for which emergence failed. The age-stage-specific aphid killing rate $\left(p_{x j}\right)$ was the number of aphid nymphs fed on by $A$. asychis at age $x$ and stage $j$, and the $p_{x j}$ value is the sum of $f_{x j}, c_{x j}$, and $d_{x j}$.

\section{Results}

\subsection{Life Table}

Overlaps between stages revealed the different developmental rates among the $A$. asychis individuals. The age-specific survival rate $\left(l_{x}\right)$ of $A$. asychis decreased gradually with increasing age. In the parent cohort, 43, 40, 40, and 26 parasitoids successfully emerged as adults at 20, 24, 28, and $32{ }^{\circ} \mathrm{C}$, respectively. The emergence rates of the parent cohort were $86 \%, 80 \%, 80 \%$, and $52 \%$ at $20,24,28$, and $32{ }^{\circ} \mathrm{C}$, respectively. The female proportion in the $20{ }^{\circ} \mathrm{C}$ treatment was significantly greater than that in the 28 ${ }^{\circ} \mathrm{C}$ treatment. The increase in temperature caused a significant decrease in the developmental time of $A$. asychis. Its adult longevity, likewise, showed the same trend (Figure 1 and Table 2).

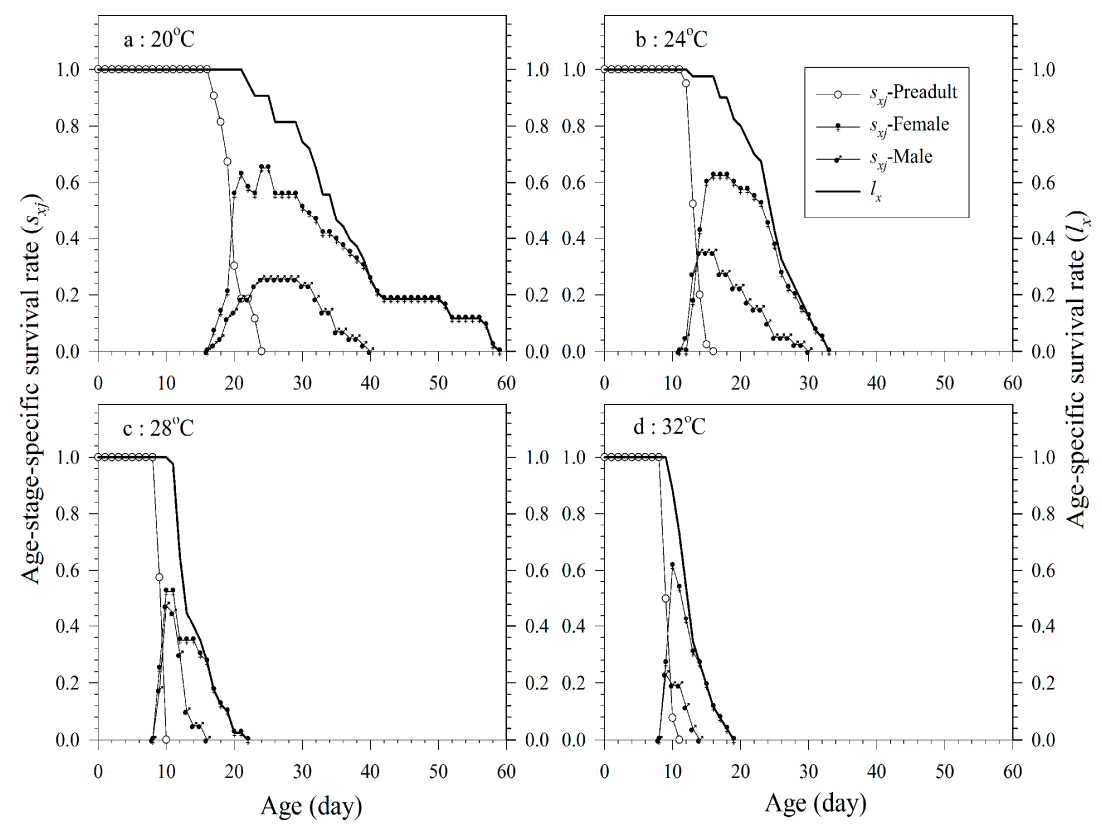

Figure 1. Age-stage-specific survival rates $\left(s_{x j}\right)$ and age-specific survival rates $\left(l_{x}\right)$ of $A$. asychis parasitizing $M$. persicae at $20^{\circ} \mathrm{C}(\mathbf{a}), 24^{\circ} \mathrm{C}(\mathbf{b}), 28^{\circ} \mathrm{C}(\mathbf{c})$ and $32{ }^{\circ} \mathrm{C}(\mathbf{d})$.

The $f_{x j}$ curve indicates the number of progeny adults produced by the female at age $x$ and stage $j$, and $f_{x 2}$ indicates that the female adult is of the second life stage. The $f_{x 2}, m_{x}$, and $l_{x} m_{x}$ of the female adult showed irregular fluctuations in all treatments. Increasing temperatures significantly decreased the reproduction period. The total number of progeny adults showed a similar trend (Figure 2 and Table 2). 
Table 2. Development and fecundity of $A$. asychis parasitizing $M$. persicae on chili peppers at four constant temperatures.

\begin{tabular}{|c|c|c|c|c|c|c|c|c|}
\hline \multirow{2}{*}{ Parameters } & \multicolumn{2}{|r|}{$20{ }^{\circ} \mathrm{C}$} & \multicolumn{2}{|r|}{$24^{\circ} \mathrm{C}$} & \multicolumn{2}{|r|}{$28^{\circ} \mathrm{C}$} & \multicolumn{2}{|r|}{$32{ }^{\circ} \mathrm{C}$} \\
\hline & $\mathbf{n}$ & Mean \pm SE & $\mathbf{n}$ & Mean \pm SE & $\mathbf{n}$ & Mean \pm SE & $\mathbf{n}$ & Mean \pm SE \\
\hline Emergence rate of the parent cohort (\%) & 43 & $86 \%$ & 40 & $80 \%$ & 40 & $80 \%$ & 26 & $52 \%$ \\
\hline Female proportion of the parent cohort (\%) & 43 & $74.4 \pm 6.7 \%$ a & 40 & $62.5 \pm 7.7 \% \mathrm{ab}$ & 40 & $52.5 \pm 7.9 \%$ bc & 26 & $65.4 \pm 9.3 \% \mathrm{ab}$ \\
\hline Female preadult duration $(\mathrm{d})$ & 32 & $20.1 \pm 0.3 \mathrm{a}$ & 25 & $14.1 \pm 0.2 \mathrm{~b}$ & 21 & $9.5 \pm 0.1 \mathrm{c}$ & 17 & $9.7 \pm 0.2 \mathrm{c}$ \\
\hline Female longevity (d) & 32 & $38.0 \pm 2.1 \mathrm{a}$ & 25 & $26.6 \pm 0.8 \mathrm{~b}$ & 21 & $16.0 \pm 0.7 \mathrm{c}$ & 17 & $14.0 \pm 0.6 \mathrm{~d}$ \\
\hline Male preadult duration (d) & 11 & $20.4 \pm 0.7 \mathrm{a}$ & 15 & $13.1 \pm 0.2 b$ & 19 & $9.6 \pm 0.1 c$ & 9 & $9.4 \pm 0.2 c$ \\
\hline Male longevity (d) & 11 & $34.6 \pm 0.9 \mathrm{a}$ & 15 & $23.4 \pm 0.9 \mathrm{~b}$ & 19 & $13.0 \pm 0.3 c$ & 9 & $11.7 \pm 0.5 \mathrm{~d}$ \\
\hline Reproduction period (d) & 32 & $16.0 \pm 2.0 \mathrm{a}$ & 25 & $11.5 \pm 0.8 \mathrm{~b}$ & 21 & $5.9 \pm 0.6 \mathrm{c}$ & 17 & $4.2 \pm 0.6 \mathrm{~d}$ \\
\hline Fecundity (progeny adults/female) & 32 & $238.6 \pm 31.0 \mathrm{a}$ & 25 & $150.3 \pm 11.8 \mathrm{~b}$ & 21 & $50.1 \pm 5.9 c$ & 17 & $11.7 \pm 2.1 \mathrm{~d}$ \\
\hline
\end{tabular}

Different letters in the same row indicate significant differences (paired bootstrap test, $p<0.05$ ).

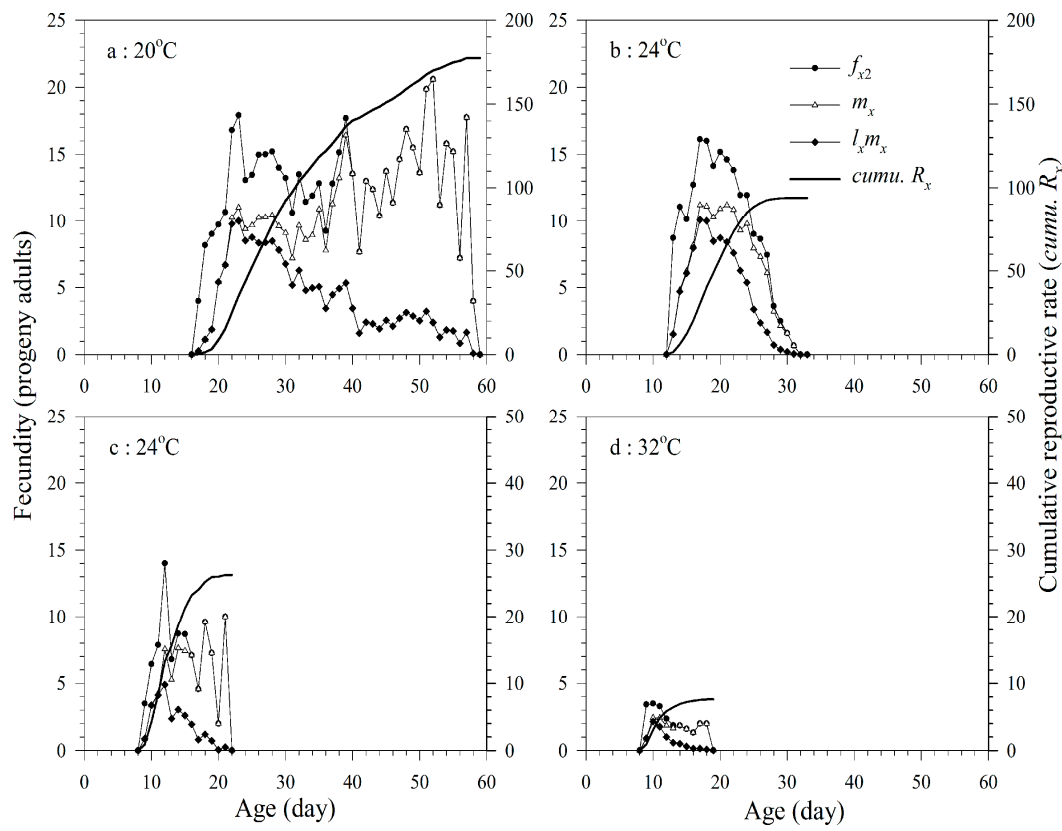

Figure 2. Age-stage-specific fecundity $\left(f_{x 2}\right)$, age-specific fecundity $\left(m_{x}\right)$, age-specific net fecundity $\left(l_{x} m_{x}\right)$, and cumulative reproductive rates $\left(\right.$ cumu. $\left.R_{x}\right)$ of $A$. asychis parasitizing M. persicae at $20^{\circ} \mathrm{C}(\mathbf{a})$, $24{ }^{\circ} \mathrm{C}(\mathbf{b}), 28^{\circ} \mathrm{C}(\mathbf{c})$ and $32{ }^{\circ} \mathrm{C}(\mathbf{d})$.

\subsection{Population Parameters}

The values of $r$ and $\lambda$ of $A$. asychis at 24 and $28^{\circ} \mathrm{C}$ were significantly greater than those at 20 and $32{ }^{\circ} \mathrm{C}$, respectively, while the $R_{0}$ and $T$ decreased significantly with increasing temperature (Table 3 ).

Table 3. Population parameters, host feeding, non-effective parasitism and aphid killing of A. asychis parasitizing $M$. persicae on chili pepper at four constant temperatures.

\begin{tabular}{ccccc}
\hline Parameters & $\mathbf{2 0}{ }^{\circ} \mathbf{C}$ & $\mathbf{2 4}{ }^{\circ} \mathbf{C}$ & $28{ }^{\circ} \mathbf{C}$ & $32{ }^{\circ} \mathbf{C}$ \\
\hline$r\left(\mathrm{~d}^{-1}\right)$ & $0.1848 \pm 0.0051 \mathrm{a}$ & $0.2360 \pm 0.0082 \mathrm{~b}$ & $0.2441 \pm 0.0140 \mathrm{~b}$ & $0.1676 \pm 0.0186 \mathrm{a}$ \\
$\lambda\left(\mathrm{d}^{-1}\right)$ & $1.2030 \pm 0.0061 \mathrm{a}$ & $1.2662 \pm 0.0103 \mathrm{~b}$ & $1.2765 \pm 0.0179 \mathrm{~b}$ & $1.1825 \pm 0.0219 \mathrm{a}$ \\
$R_{0}$ (progeny adults) & $177.5 \pm 27.6 \mathrm{a}$ & $94.0 \pm 13.6 \mathrm{~b}$ & $26.3 \pm 5.0 \mathrm{c}$ & $7.6 \pm 1.7 \mathrm{~d}$ \\
$T(\mathrm{~d})$ & $28.0 \pm 0.5 \mathrm{a}$ & $19.2 \pm 0.2 \mathrm{~b}$ & $13.4 \pm 0.3 \mathrm{c}$ & $12.1 \pm 0.2 \mathrm{~d}$ \\
\hline$C_{0}$ (aphids) & $26.6 \pm 4.0 \mathrm{a}$ & $18.2 \pm 2.7 \mathrm{~b}$ & $6.9 \pm 1.4 \mathrm{c}$ & $3.0 \pm 0.6 \mathrm{~d}$ \\
$N_{0}$ (aphids) & $18.7 \pm 3.0 \mathrm{a}$ & $11.9 \pm 1.7 \mathrm{a}$ & $5.5 \pm 1.3 \mathrm{~b}$ & $3.3 \pm 0.8 \mathrm{~b}$ \\
\hline$Z_{0}$ (aphids) & $222.8 \pm 34.4 \mathrm{a}$ & $124.0 \pm 17.4 \mathrm{~b}$ & $38.6 \pm 7.3 \mathrm{c}$ & $14.0 \pm 2.9 \mathrm{~d}$ \\
$\vartheta$ & $0.2610 \pm 0.0145 \mathrm{a}$ & $0.3550 \pm 0.0235 \mathrm{~b}$ & $0.4241 \pm 0.0412 \mathrm{~b}$ & $0.3647 \pm 0.0371 \mathrm{~b}$ \\
$\theta$ & $0.3140 \pm 0.0190 \mathrm{a}$ & $0.4495 \pm 0.0333 \mathrm{~b}$ & $0.5414 \pm 0.0595 \mathrm{~b}$ & $0.4312 \pm 0.0511 \mathrm{~b}$ \\
$Q_{p}$ & $1.2552 \pm 0.0124 \mathrm{a}$ & $1.3201 \pm 0.0166 \mathrm{~b}$ & $1.4691 \pm 0.0429 \mathrm{c}$ & $1.8333 \pm 0.0680 \mathrm{~d}$ \\
\hline
\end{tabular}

Different letters in the same row indicate significant differences (paired bootstrap test, $p<0.05$ ). 


\subsection{Host Feeding}

The Aphelinus asychis eggs, larvae, and pupae are in host bodies all the time, and this host is regarded as the parental parasitism. Therefore, the host feeding rate dose not exist before the female adult stage. All the $k_{x}$ of the adult female of $A$. asychis showed irregular undulation at 20, 24, 28, and $32{ }^{\circ} \mathrm{C}$. The maximum daily $k_{x}$ at $20,24,28$, and $32{ }^{\circ} \mathrm{C}$ were $2.4,2.1,3.0$, and 1.3 aphids at ages 47 , 22,18 , and $12 \mathrm{~d}$, respectively. The maximum daily values of $q_{x}$ at $20,24,28$, and $32^{\circ} \mathrm{C}$ were $2.1,1.8,1.2$, and 0.7 aphids at ages $25,17,10$, and $12 \mathrm{~d}$, respectively. Increasing the temperature decreased the $C_{0}$ of the aphids that were killed by A. asychis (Table 3 and Figure 3 ).

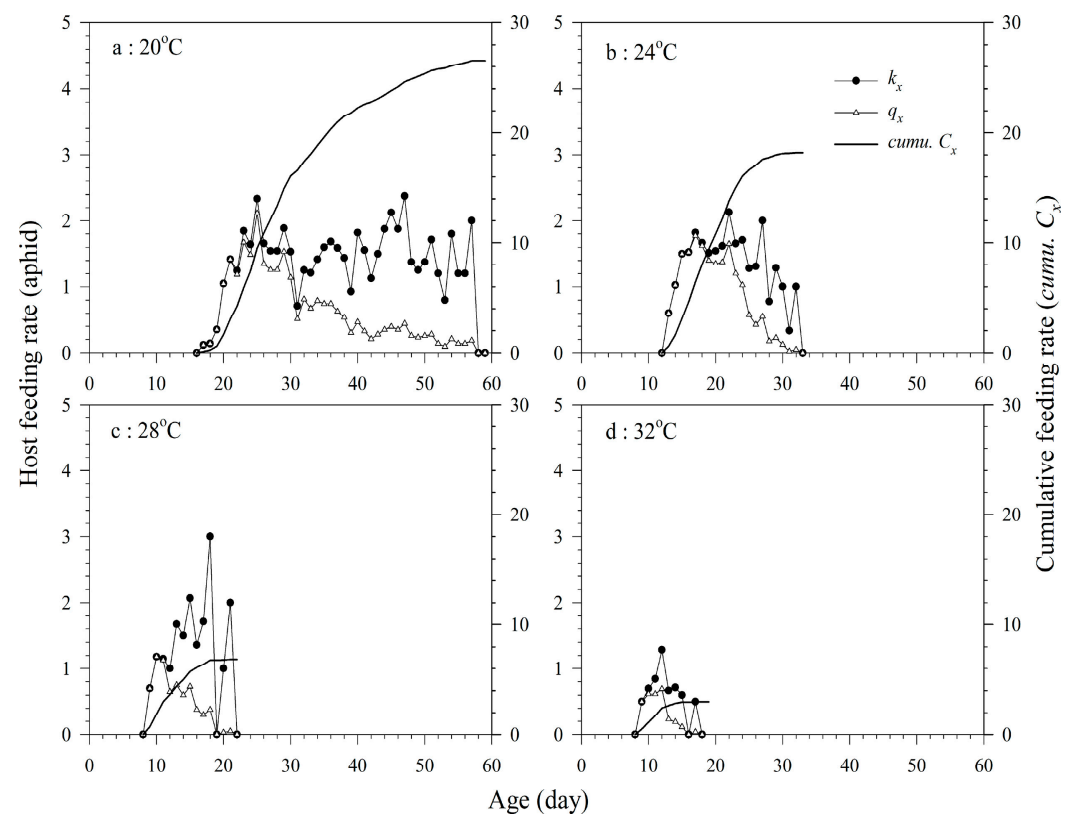

Figure 3. Age-specific host feeding rates $\left(k_{x}\right)$, age-specific net host feeding rates $\left(q_{x}\right)$, and cumulative host feeding rates (cumu. $\left.C_{x}\right)$ of $A$. asychis parasitizing M. persicae at $20^{\circ} \mathrm{C}(\mathbf{a}), 24^{\circ} \mathrm{C}(\mathbf{b}), 28^{\circ} \mathrm{C}(\mathbf{c})$ and $32{ }^{\circ} \mathrm{C}(\mathbf{d})$.

\subsection{Non-Effective Parasitism}

Because $A$. asychis could not parasitize aphids during the pre-adult stage, there was no non-effective parasitism rate before adult emergence. The $g_{x}$ of $A$. asychis showed irregular fluctuation in all treatments. The maximum daily $g_{x}$ at $20,24,28$, and $32^{\circ} \mathrm{C}$ were $3.6,1.7,4.0$, and 3.2 aphids at ages $52,22,21$, and $15 \mathrm{~d}$, respectively. The maximum daily values of $h_{x}$ at $20,24,28$, and $32{ }^{\circ} \mathrm{C}$ were $1.0,1.4,0.8$, and 0.7 aphids at ages $25,19,13$, and $10 \mathrm{~d}$, respectively. Increasing the temperature significantly decreased the $N_{0}$ of $A$. asychis (Table 3 and Figure 4).

\subsection{Aphid Killing Rate}

Because immature $A$. asychis could not parasitize and feed on aphids, its killing rate during the pre-adult stage could not be determined. The daily $u_{x}$ of the adult females of $A$. asychis showed irregular undulation at $20,24,28$, and $32{ }^{\circ} \mathrm{C}$. The maximum $u_{x}$ at $20,24,28$, and $32{ }^{\circ} \mathrm{C}$ were 25.4 , $13.7,16.0$, and 5.4 aphids, respectively. The maximum daily values of $w_{x}$ in the $20,24,28$, and $32{ }^{\circ} \mathrm{C}$ treatments were $12.6,13.0,6.2$, and 3.5 aphids, respectively. The $Z_{0}$ of aphids by $A$. asychis were 222.8, 124.0, 38.6, and 14.0 aphids per individual at 20, 24, 28, and $32{ }^{\circ} \mathrm{C}$, respectively. The $\theta$ at 20, 24, 28, and $32^{\circ} \mathrm{C}$ were $0.3140,0.4495,0.5414$, and 0.4312 , respectively. The $Q_{p}$ value of $A$. asychis increased significantly with increasing temperature (Figure 5 and Table 3 ). 


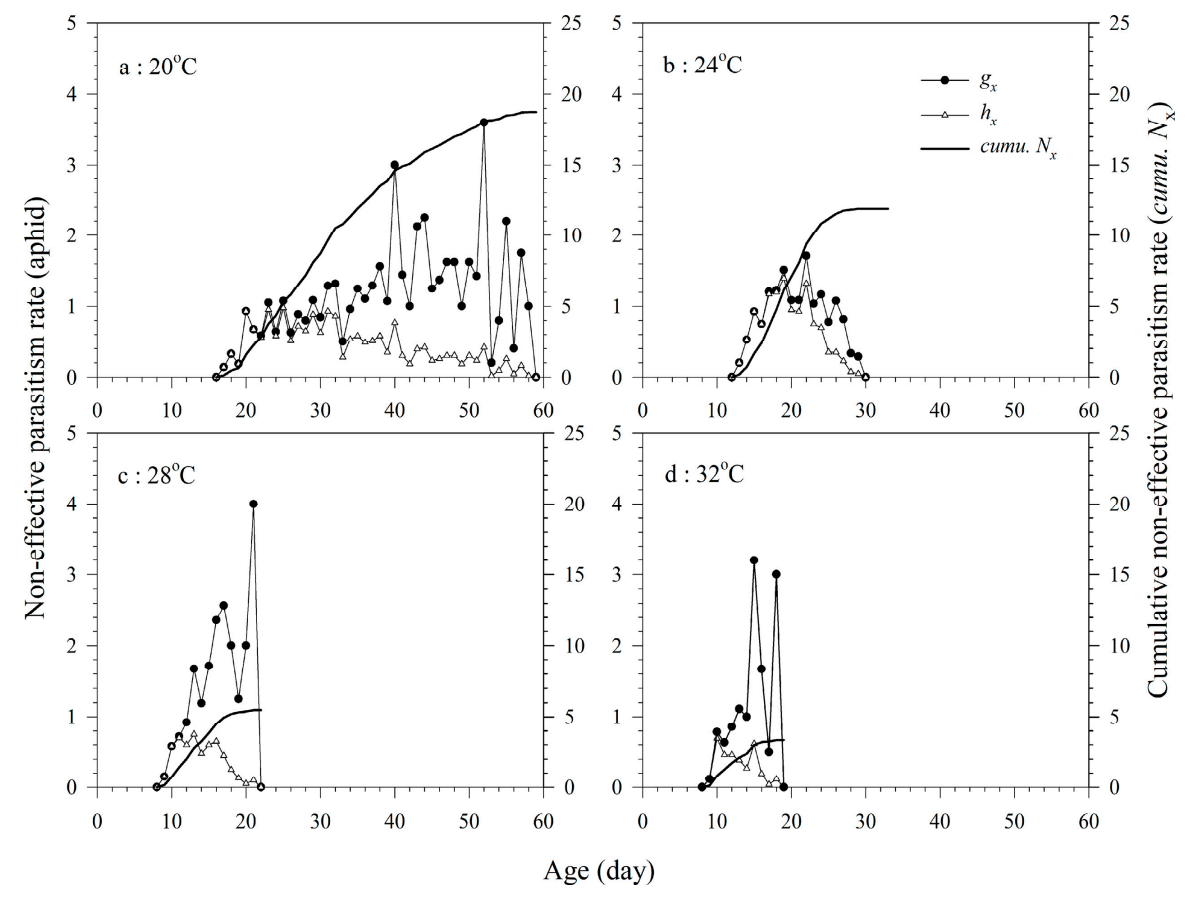

Figure 4. Age-specific non-effective parasitism rates $\left(g_{x}\right)$, age-specific net non-effective parasitism rates $\left(h_{x}\right)$, and cumulative non-effective parasitism rates (cumu. $N_{x}$ ) of A. asychis parasitizing M. persicae at $20{ }^{\circ} \mathrm{C}(\mathbf{a}), 24^{\circ} \mathrm{C}(\mathbf{b}), 28^{\circ} \mathrm{C}(\mathbf{c})$ and $32{ }^{\circ} \mathrm{C}(\mathbf{d})$.

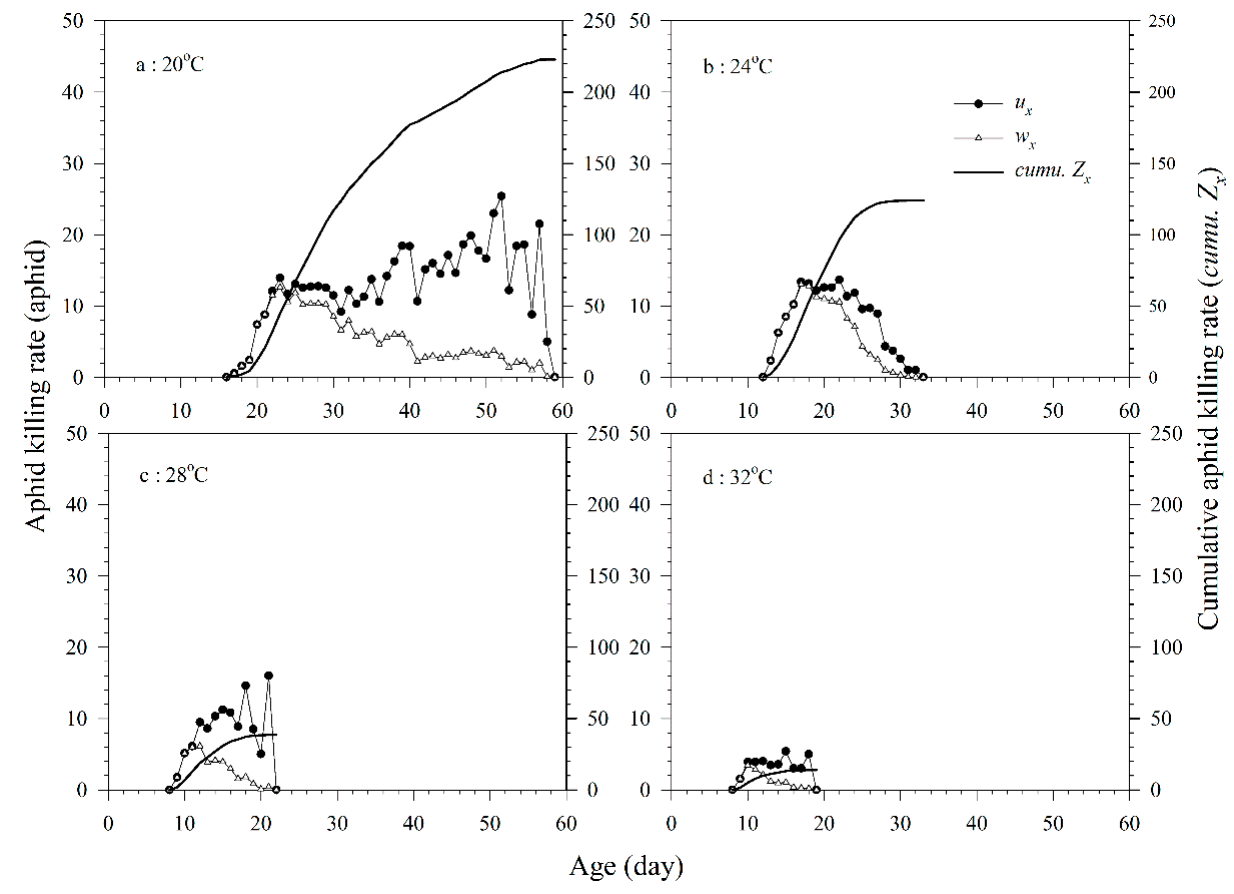

Figure 5. Age-specific aphid killing rates $\left(u_{x}\right)$, age-specific net aphid killing rates $\left(w_{x}\right)$, and cumulative killing rates (cumu. $Z_{x}$ ) of $A$. asychis parasitizing M. persicae at $20^{\circ} \mathrm{C}(\mathbf{a}), 24^{\circ} \mathrm{C}(\mathbf{b}), 28^{\circ} \mathrm{C}(\mathbf{c})$ and $32{ }^{\circ} \mathrm{C}(\mathbf{d})$.

\subsection{Relationship between Population Fitness and Temperatures}

The relationship between population fitness $\left(R_{0}, C_{0}, r\right.$, and $\left.\theta\right)$ and temperature is shown in Figure 6. The relationship between population fitness (the net reproductive rate, net feeding rate, intrinsic rate of increase, and finite aphid killing rate) and temperature followed a unary quadratic function as evidenced by the high coefficient of determination $\left(R^{2}\right)$, greater than 0.95 . The net reproductive 
rate and net host feeding rate decreased as the temperature increased within the range 20 to $32{ }^{\circ} \mathrm{C}$. The temperature for the expected maximum intrinsic rate of increase $\left(25.7^{\circ} \mathrm{C}\right)$ was lower than that for the maximum finite killing rate $\left(27.4{ }^{\circ} \mathrm{C}\right)$.
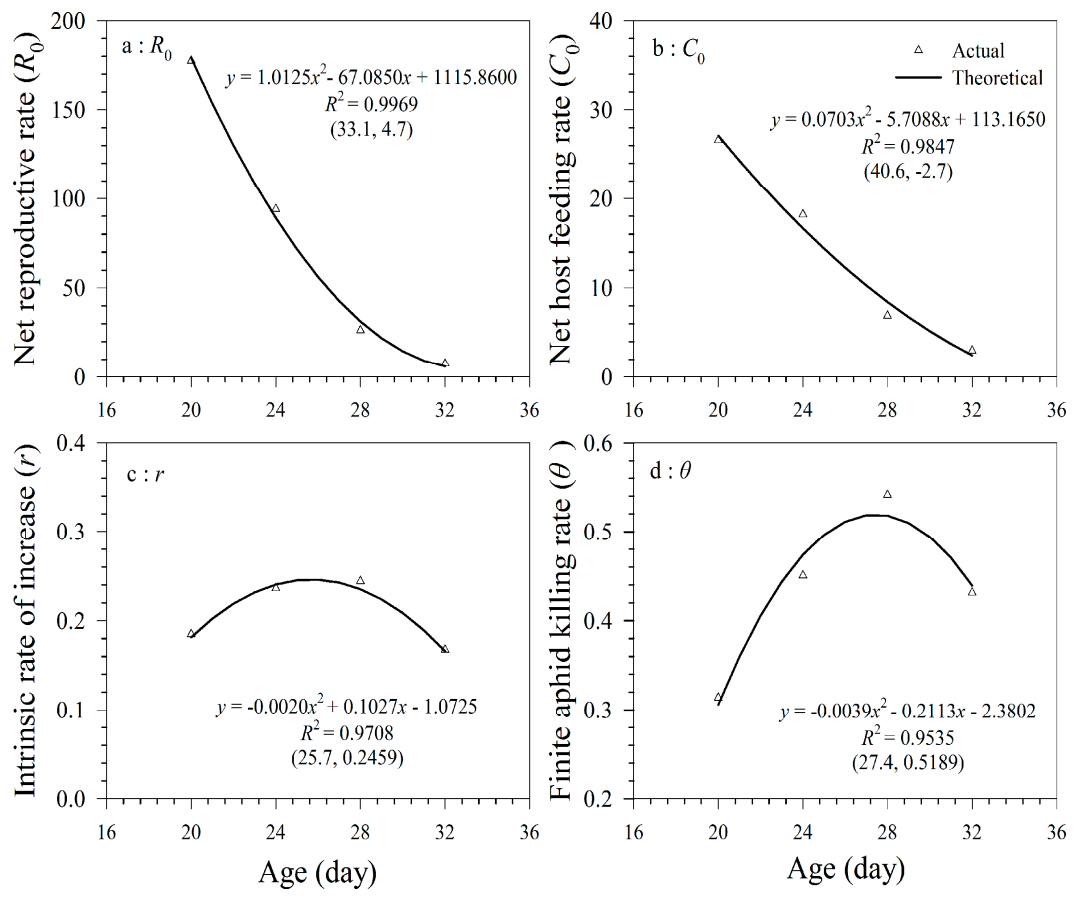

Figure 6. Relationship between population fitness and temperature of $A$. asychis parasitizing $M$. persicae at $20^{\circ} \mathrm{C}(\mathbf{a}), 24^{\circ} \mathrm{C}(\mathbf{b}), 28^{\circ} \mathrm{C}(\mathbf{c})$ and $32{ }^{\circ} \mathrm{C}(\mathbf{d})$.

The population projection showed that $A$. asychis increased much faster at 24 and $28^{\circ} \mathrm{C}$ (Figure 7). Because the $A$. asychis female does not feed on another host before the adult stage, and male adult does not feed on aphid, the trend of the total population size was different from that of the killing potential. The curve of the female population size showed, however, a similar trend to that of the killing potential.

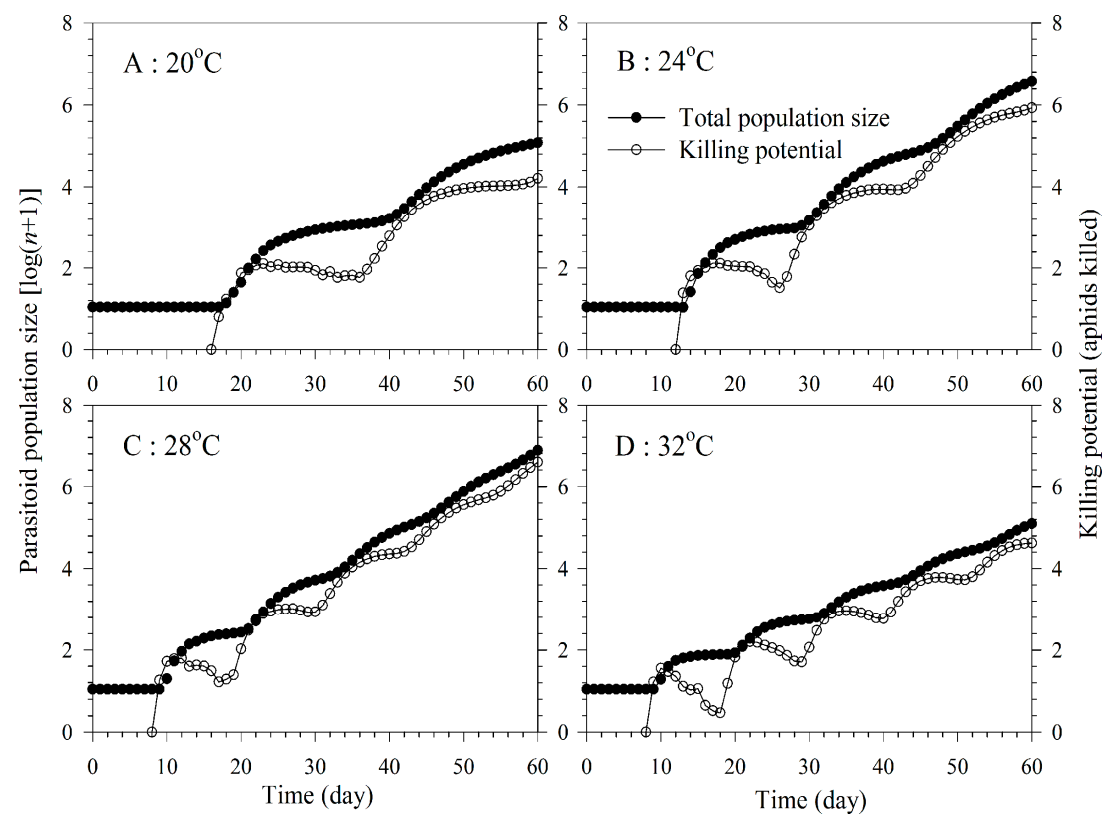

Figure 7. Simulated population growth and killing potential of A. asychis parasitizing M. persicae at $20^{\circ} \mathrm{C}(\mathbf{a}), 24^{\circ} \mathrm{C}(\mathbf{b}), 28^{\circ} \mathrm{C}(\mathbf{c})$ and $32{ }^{\circ} \mathrm{C}(\mathbf{d})$. 


\section{Discussion}

Temperature is a vital factor that affects the population fitness of insects, of which the optimal for various insect species may vary $[48,49]$. In this study, the population fitness of $A$. asychis was evaluated at four constant temperatures. Aphelinus asychis could survive and produce progenies at all four temperatures, but higher fitness $\left(r\right.$ and $\theta$ ) was observed at moderate temperature $\left(24\right.$ and $\left.28^{\circ} \mathrm{C}\right)$. The fitting of the data to a unary quadratic function showed that the temperatures for the expected maximum intrinsic rate of increase $\left(r_{\max }\right)$ and the maximum finite killing rate $\left(\theta_{\max }\right)$ were 25.7 and $27.4^{\circ} \mathrm{C}$, respectively. In addition, the temperature for the $r_{\max }$ of $M$. persicae was between 20 and $25^{\circ} \mathrm{C}$ [50]. Thus, we inferred that the best temperature range for controlling M. persicae with A. asychis as a biological agent in chili pepper fields might be $25.7-27.4{ }^{\circ} \mathrm{C}$.

Numerous factors might affect the developmental time of A. asychis. Aphelinid wasps, in general, have a developmental time of 15-30 days [13,51-53]. Specifically, the developmental times of $A$. asychis at 23.9 and $32.2^{\circ} \mathrm{C}$ have been determined to be 16 and 10 days, respectively [54]. We found that increasing the temperature significantly decreased the developmental time of the $A$. asychis female and male. The developmental duration of $A$. asychis females and males was significantly affected by host age when it fed on Aphis gossypii, which was $14.5 \mathrm{~d}$ and $14.4 \mathrm{~d}$ in 1-2 day old A. gossypii-nymphs, $13.5 \mathrm{~d}$ and $13.1 \mathrm{~d}$ in 4-5 day old nymphs, and $12.3 \mathrm{~d}$ and $12.2 \mathrm{~d}$ with $A$. gossypii adults as the hosts at $25^{\circ} \mathrm{C}$, respectively [53]. Additionally, the developmental times of the $A$. asychis female and male from the egg to the adult stage and parasitization of $A$. gossypii at $25^{\circ} \mathrm{C}$ were 13.9 and $13.2 \mathrm{~d}$, respectively [55]. When it parasitized $A$. gossypii at 20,25 , and $30^{\circ} \mathrm{C}$, the developmental times were 20.6, 14.2, and $13.0 \mathrm{~d}$ respectively [56]. Differences among these parameters may be attributed to the temperature, host species, and host stage.

In previous studies, both host species and stage were reported to affect the proportions of $A$. asychis female adults $[54,57]$. When the Schizaphis graminum nymph was used as a host, the older-aged nymphs produced a higher proportion of $A$. asychis female progenies [58]. The proportions of $A$. asychis that parasitized 1-2-day-old and 4-5-day-old A. gossypii nymphs and adults were $47.4 \%, 41.2 \%$, and $47.7 \%$, respectively [53]. Additionally, the proportion of female adults produced by $A$. asychis parasitizing a combination of second and third instar A. gossypii nymphs was 51.9\% [55]. The temperature under which the parasitoids are reared may also affect sex ratio. For instance, the highest portion of females on Diaeretiella rapae was $70 \%$ at $7.2^{\circ} \mathrm{C}$, and the lowest was $50 \%$ at $29.4^{\circ} \mathrm{C}$ [59]. Kang et al. reported that the percentages of female adults were $71.7 \%, 65.0 \%$, and $78.8 \%$ at 20,25 , and $30{ }^{\circ} \mathrm{C}$, respectively [56]. This was similar to our results.

Many biotic and abiotic factors, including the host species, host plant, and temperature, could affect the longevity of $A$. asychis. For example, the longevity of $A$. asychis female adults when they parasitized S. graminum, Rhopalosiphum maidis, or Sipha flava was similar with some variation-about 18 days under greenhouse conditions [54], 20 days when they parasitized S. graminum under field conditions [57], 21 days when they parasitized the second and third instar nymphs of $A$. gossypii at $25{ }^{\circ} \mathrm{C}$ [55], and 23 days with second instar nymphs of $M$. persicae on chili peppers at $25^{\circ} \mathrm{C}$ [13]. In this study, we found that increasing the temperature significantly decreased the total longevity of $A$. asychis, and the adult longevities of the females and males showed similar responses to temperature.

In this study, the number of progeny adults of the parasitoids decreased significantly as the temperature increased. When they parasitized S. graminum, R. maidis, and S. flava at 23.9, 26.7, 29.4, and $32.2^{\circ} \mathrm{C}$, the number of $A$. asychis progeny was less than 200 [54]. A. asychis females produced 232.3, 44.7, and 21.1 eggs when they parasitized 1-2-day-old A. gossypii nymphs, adults, and 4-5-day-old nymphs, respectively [53]. When $A$. gossypii was used as a host, $A$. asychis females produced an average of 342.9 mummified aphids at $25^{\circ} \mathrm{C}$ [55], which was more than that at $24{ }^{\circ} \mathrm{C}$ in this study. When it parasitized the second instar nymph of $M$. persicae on chili peppers at $25^{\circ} \mathrm{C}$, each $A$. asychis female produced more eggs (414.6) than that (238.6 eggs) recorded at all four constant temperatures in this study [13]. The difference between these studies may be due to many factors, including the host species, parasitoid strains, or host plants. 
Moreover, the $R_{0}$ of $A$. asychis in this study showed a significant decrease with a temperature increase, which indicated that the $R_{0}$ was negatively influenced by temperature. The regression equation for $R_{0}$ and temperature supports this phenomenon. In this study, the temperature for the expected maximum intrinsic rate of increase $\left(25.7^{\circ} \mathrm{C}\right)$ was lower than that for the maximum finite killing rate $\left(27.4^{\circ} \mathrm{C}\right)$. This shows that the different population characteristics (i.e., population growth and parasitism rate) may respond differently to environmental factors.

The host feeding behaviors of $A$. asychis on some host species have been previously studied. It was noted that aphids fed on by $A$. asychis females were first paralyzed and usually died after feeding [18]. In addition, A. gossypii nymphs and adults were acceptable for host feeding by A. asychis, and the number of younger instar aphids for host feeding was higher than that of older instars [53]. They speculated that older aphids were larger and richer in nutrients than the younger nymphs, so the female parasitoids needed more young nymphs to obtain nutrients for oogenesis. Additionally, the aphid's defense reactions may lead to the preference of aphelinids for younger hosts [60-62]. Furthermore, the average number of $A$. gossypii infesting cucumbers (Cucumis sativus) and killed by A. asychis by non-reproductive host killing was 73.9 [63]. As shown in our study, an increase in the rearing temperature significantly decreased the $C_{0}$, and the regression equation for $C_{0}$ and temperature showed a similar decreasing tendency from 20 to $30^{\circ} \mathrm{C}$. However, the $g_{x}$ showed an irregular variation in the adult stage at all four constant temperatures, and it was higher at mid-term than prophase. This phenomenon indicated that the emergence rate for progenies in the next generation was influenced by female adult age, which was also found in our previous study [13]. In addition, the $N_{0}$ of aphids killed by $A$. asychis decreased significantly with increasing temperature in this study, which suggested that $N_{0}$ might be influenced by temperature.

In this study, the $r$ of $A$. asychis in the 24 and $28^{\circ} \mathrm{C}$ treatments were significantly greater than those in the 20 and $32{ }^{\circ} \mathrm{C}$ treatments, which suggested that increasing the temperature benefited the $r$, but a further increase in temperature negatively affected the population parameter. The $r$ of $A$. asychis feeding on $A$. gossypii nymphs was 0.255 at $25{ }^{\circ} \mathrm{C}$ [55], which was much greater than that at 20 to $32{ }^{\circ} \mathrm{C}$ in our study. The differences between the two studies might be influenced by the host species and temperature.

It is well known that the ability of a natural enemy to kill a pest in a lifespan partially represents its control efficiency. For the age-stage distribution of a stable population, the $\theta$ was used to compare the control potential of the natural enemy [43,64]. Our research results showed that the $\theta$ of $A$. asychis gradually decreased significantly with increasing temperature. Therefore, the killing potential of A. asychis for M. persicae on chili peppers was affected by temperature, but the most suitable temperature was around $24^{\circ} \mathrm{C}$.

Aphelinus asychis has a wide distribution in Asia, Europe, and North and South America [65], and has been used in Russia, China, South Korea, Japan, and America $[13,17,22,59,66]$, but the climates in these regions and countries vary. Kalinkat et al. suggested that climate change may influence the functional responses of parasitoid-host pairs via temperature [67]. Temperature is the primary abiotic factor of climate change, which may affect insect development, reproduction, parasitizing behavior, distribution range, and biological clock [68-71]. The capacities of insects to adapt to new environmental conditions might be conferred by either plasticity or genetic evolution [37]. The difference in the population fitness of $A$. asychis at the four constant temperatures might be related to a similar mechanism. However, the exact mechanism of adaptation to these circumstances in $A$. asychis remains unclear and should be studied in the future. In addition, the control efficiency of $A$. asychis for M. persicae under greenhouse and field conditions, in which the temperature could be varied greatly, need to be tested in future research.

\section{Conclusions}

Aphelinus asychis could develop from egg to adult and reproduce successfully within a temperature range of $20-32{ }^{\circ} \mathrm{C}$. The intrinsic rate of increase $(r)$ of $A$. asychis at 24 and $28{ }^{\circ} \mathrm{C}$ was greater than that at 20 and $32{ }^{\circ} \mathrm{C}$, and the finite aphid killing rates $(\theta)$ at 24,28 , and $32{ }^{\circ} \mathrm{C}$ were better than that at $20^{\circ} \mathrm{C}$. 
The population projection showed that $A$. asychis increased much faster at 24 and $28{ }^{\circ} \mathrm{C}$. The results of fitting data showed that the temperatures for the expected maximum intrinsic rate of increase $\left(r_{\max }\right)$ and the maximum finite killing rate $\left(\theta_{\max }\right)$ were 25.7 and $27.4{ }^{\circ} \mathrm{C}$, respectively, which suggested that the most suitable range of temperatures for $A$. asychis for controlling $M$. persicae in chili pepper fields might be between 25.7 and $27.4{ }^{\circ} \mathrm{C}$.

Author Contributions: Methodology, S.Y.W. and Y.H.L.; data analyses, S.Y.W., B.L.W., and D.Y.Z.; writing一original draft preparation, S.Y.W., G.L.Y., and T.X.L.; writing-review and editing, S.Y.W. and T.X.L. All authors have read and agreed to the published version of the manuscript.

Funding: This work was supported by the National Natural Science Foundation, China (Grant No. 31701848); China Agriculture Research System (No. CARS-23-D06); Natural Science Foundation of Zhejiang province, China (LGN19C140007); and Research Foundation of Zhejiang A\&F University (2017FR007).

Acknowledgments: We are grateful for the assistance of all teachers and students at Northwest A\&F University and Zhejiang A\&F University for this study.

Conflicts of Interest: All authors declare no conflict of interest.

\section{References}

1. Wang, Q.B.; Zhang, Y.Y.; Zhuang, M.; Yang, L.M.; Liu, Y.M.; Lü, H.H.; Fang, Z.Y. EST-SSR fingerprinting of fifty cabbage representative varieties from China. Sci. Agric. Sin. 2014, 47, 111-121.

2. Van Emden, H.F.; Van Eastop, V.F.; Hughes, R.D.M.J.; Way, M.J. The Ecology of Myzus persicae. Annu. Rev Entomol. 2003, 14, 197-270. [CrossRef]

3. Sun, H.; Song, Y. Establishment of a wheat banker plant system for the parasitoid Aphidius gifuensis against Myzus persicae in greenhouse chili pepper. Appl. Entomol. Zool. 2019, 54, 1-9. [CrossRef]

4. Voudouris, C.C.; Kati, A.N.; Sadikoglou, E.; Williamson, M.; Skouras, P.; Dimotsiou, O.; Georgiou, S.; Fenton, B.; Skavdis, G.; Margaritopoulos, J.T. Insecticide resistance status of Myzus persicae in Greece: Long term surveys and new diagnostics for resistance mechanisms.: Resistance status of M. persicae in Greece. Pest Manag. Sci. 2015, 72, 671-683. [CrossRef] [PubMed]

5. Needham, P.H.; Sawicki, R.M. Diagnosis of resistance to organophosphorus insecticides in Myzus persicae. Nature 1971, 230, 125-126. [CrossRef]

6. Martinez-Torres, D.; Foster, S.P.; Field, L.M.; Devonshire, A.L.; Williamson, M.S. A sodium channel point mutation is associated with resistance to DDT and pyrethroid insecticides in the peach-potato aphid, Myzus persicae (Sulzer) (Hemiptera: Aphididae). Insect Biochem. Mol. 1999, 8, 339-346. [CrossRef]

7. Ffrench-Constant, R.H.; Anthony, N.; Aronstein, K.; Rocheleau, T.; Stilwell, G. Cyclodiene insecticide resistance: From molecular to population genetics. Annu. Rev. Entomol. 2000, 45, 449-466. [CrossRef]

8. Philippou, D.; Field, L.M.; Moores, G.D. Metabolic enzyme(s) confer imidacloprid resistance in a clone of Myzus persicae (Sulzer) (Hemiptera: Aphididae) from Greece. Pest Manag. Sci. 2009, 66, 390-395.

9. Suwignyo, R.A.; Napoleon, A. Insecticides residue in the centre of paddy field in Musi Rawas, South Sumatera, Indonesia. E3s Web Conf. 2018, 68, 04014.

10. Bucy, M.T.; Melathopoulos, A. Labels of insecticides to which Oregon honey bee (Apis mellifera L.) hives could be exposed do not align with federal recommendations in their communication of acute and residual toxicity to honey bees. Pest Manag. Sci. 2020, 76, 1664-1672. [CrossRef]

11. Heller, S.; Joshi, N.K.; Chen, J.; Rajotte, E.G.; Mullin, C.; Biddinger, D.J. Pollinator exposure to systemic insecticides and fungicides applied in the previous fall and pre-bloom period in apple orchards. Environ. Pollut. 2020, 265, 114589. [CrossRef] [PubMed]

12. Frank, S.D. Biological control of arthropod pests using banker plant systems: Past progress and future directions. Biol. Control 2010, 52, 8-16. [CrossRef]

13. Wang, S.Y.; Chi, H.; Liu, T.X. Demography and parasitic effectiveness of Aphelinus asychis reared from Sitobion avenae as a biological control agent of Myzus persicae reared on chili pepper and cabbage. Biol. Control 2016, 92, 111-119. [CrossRef]

14. Wang, S.Y.; Feng, Y.; Liang, N.N.; Tang, R.; Liu, Y.H.; Zhang, D.Y.; Liu, T.X. Starving Aphelinus asychis negatively affects host feeding and parasitism on Myzus persicae. J. Asia-Pac. Entomol. 2018, 21, 676-681. [CrossRef] 
15. Hayat, M. The genera of Aphelinidae (Hymenoptera) of the world. Syst. Entomol. 1983, 8, 63-102. [CrossRef]

16. Japoshvili, G.; Karaca, I. A review of the species of Aphelinus Dalman, 1820 (Hymenoptera: Aphelinidae) from Georgia. J. Entomol. Res. Soc. 2009, 11, 41-52.

17. Li, C.D.; Byeon, Y.W.; Choi, B.R. An aphelinid species, Aphelinus asychis Walker (Hymenoptera: Aphelinidae) new to Korea. J. Asia-Pac. Entomol. 2007, 10, 13-15. [CrossRef]

18. Kumar, S.; Kashyap, S.; Soni, S. The foraging behaviour of Aphelinus asychis Walker (Hymenoptera: Aphelinidae) and Aphidius ervi (Haliday) (Hymenoptera: Braconidae) on Myzus persicae (Sulzer) (Hemiptera: Aphididae). Phytoparasitica 2019, 47, 1-10. [CrossRef]

19. Gavkare, O.; Kumar, S.; Japoshvili, G. Effectiveness of native parasitoids of Myzus persicae in greenhouse environments in India. Phytoparasitica 2014, 42, 141-144. [CrossRef]

20. Pan, M.Z.; Wang, L.; Zhang, C.Y.; Zhang, L.X.; Liu, T.X. The influence of feeding and host deprivation on egg load and reproduction of an aphid parasitoid, Aphidius gifuensis, (hymenoptera: Braconidae). Appl. Entomol. Zool. 2017, 52, 1-9. [CrossRef]

21. Takada, H. Parasitoids (Hymenoptera: Braconidae, Aphidiinae, Aphelinidae) of four principal pest aphids (Homoptera: Aphididae) on greenhouse vegetable crops in Japan. Appl. Entomol. Zool. 2002, 37, $237-249$. [CrossRef]

22. Tatsumi, E.; Takada, H. Evaluation of Aphelinus asychis and Aphelinus albipodus (Hymenoptera: Aphelinidae) as biological control agents against three pest aphids. Appl. Entomol. Zool. 2005, 40, 379-385. [CrossRef]

23. Xiao, Y.; Osborne, L.S.; Chen, J.; Mckenzie, C.; Houben, K.; Irizarry, F. Evaluation of corn plant as potential banker plant for supporting predatory gall midge, Feltiella acarisuga (Diptera: Cecidomyiidae) against Tetranychus urticae (Acari: Tetranychidae) in greenhouse vegetable production. Crop Prot. 2011, 30, 1635-1642. [CrossRef]

24. Xiao, Y.; Chen, J.; Cantliffe, D.; Mckenzie, C.; Houben, K.; Osborne, L.S. Establishment of papaya banker plant system for parasitoid, Encarsia sophia (Hymenoptera: Aphilidae) against Bemisia tabaci (Hemiptera: Aleyrodidae) in greenhouse tomato production. Biol. Control 2011, 58, 239-247. [CrossRef]

25. Messelink, G.J.; Bennison, J.; Alomar, O.; Ingegno, B.L.; Tavella, L.; Shipp, L.; Palevsky, E.; Wäckers, F.L. Approaches to conserving natural enemy populations in greenhouse crops: Current methods and future prospects. BioControl 2014, 59, 1-17. [CrossRef]

26. Pan, M.Z.; Liu, T.X. Suitability of three aphid species for Aphidius gifuensis (Hymenoptera: Braconidae): Parasitoid performance varies with hosts of origin. Biol. Control 2014, 69, 90-96. [CrossRef]

27. Pan, M.Z.; Cao, H.H.; Liu, T.X. Effects of winter wheat cultivars on the life history traits and olfactory response of Aphidius gifuensis. Biocontrol 2014, 59, 539-546. [CrossRef]

28. Inward, D.J.G.; Wainhouse, D.; Peace, A. The effect of temperature on the development and life cycle regulation of the pine weevil Hylobius abietis and the potential impacts of climate change. Agric. For. Entomol. 2012, 14, 348-357. [CrossRef]

29. Romo, C.M.; Tylianakis, J.M. Elevated temperature and drought interact to reduce parasitoid effectiveness in suppressing hosts. PLoS ONE 2013, 8, e58136. [CrossRef]

30. Piyaphongkul, J.; Pritchard, J.; Bale, J. Effects of acclimation on the thermal tolerance of the brown planthopper Nilaparvata lugens (Stål). Agric. For. Entomol. 2014, 16, 174-183. [CrossRef]

31. Zhang, S.Z.; Cao, Z.; Zhang, F.; Liu, T.X. Exposing eggs to high temperatures affects the development, survival and reproduction of Harmonia axyridis. J. Therm. Biol. 2014, 39, 40-44. [CrossRef]

32. Qin, Y.J.; Lan, S.; Zhao, Z.H.; Sun, H.Y.; Zhu, X.M.; Yang, P.Y.; Li, Z.H. Potential geographical distribution of the fall armyworm (Spodoptera frugiperda) in China. Plant Protect. 2019, 45, 43-47.

33. Wu, X. Temperature effects on development and fecundity of Aphidius gifuensis ashmead. Zool. Res. 2000, 21, 192-198.

34. Vet, L.; Lenteren, J.C.; Woets, J. The parasite-host relationship between Encarsia formosa (Hymenoptera: Aphelinidae) and Trialeurodes vaporariorum (Homoptera: Aleyrodidae). IX. A review of the biological control of the greenhouse whitefly with suggestions for future research. Entomol. Exp. Appl. 2010, 90, $26-51$. [CrossRef]

35. Zhou, Z.S.; Guo, J.Y.; Chen, H.S.; Wan, F.H. Effects of temperature on survival, development, longevity, and fecundity of Ophraella communa (Coleoptera: Chrysomelidae), a potential biological control agent against Ambrosia artemisiifolia (Asterales: Asteraceae). Environ. Entomol. 2010, 39, 1021-1027. [CrossRef] 
36. Khan, J.; Saljoki, A.U.; Rehman, A. Effect of temperature on biological attributes and predatory potential of Harmonia dimidiata (Fab.) (Coleoptera: Coccinellidae) fed on Rhopalosiphum padi aphid. J. Entomol. Zool. Stud. 2016, 4, 1016-1022.

37. Tougeron, K.; Brodeur, J.; Le Lann, C.; Van Baaren, J. How climate change affects the seasonal ecology of insect parasitoids. Ecol. Entomol. 2020, 45, 167-181. [CrossRef]

38. Hansen, L.S.; Jensen, K.M.V. Effect of temperature on parasitism and host-feeding of Trichogramma turkestanica (Hymenoptera: Trichogrammatidae) on Ephestia kuehniella (Lepidoptera: Pyralidae). J. Econ. Entomol. 2002, 95, 50-56. [CrossRef]

39. Daane, K.M.; Malakar-Kuenen, R.D.; Walton, V.M. Temperature dependent development of Anagyrus pseudococci (Hymenoptera: Encyrtidae) as a parasitoid of the vine mealybug, Planococcus ficus (Homoptera: Pseudococcidae). Biol. Control 2004, 31, 123-132. [CrossRef]

40. Chi, H.; Liu, H. Two new methods for the study of insect population ecology. Bull. Inst. Zool. Acad. Sin. 1985, 24, 225-240.

41. Chi, H. Life-table analysis incorporating both sexes and variable development rates among individuals. Environ. Entomol. 1988, 17, 26-34. [CrossRef]

42. Chi, H. TWOSEX-MSChart: Computer Program for Age Stage, Two-Sex Life Table Analysis. 2020. Available online: http://140.120.197.173/Ecology/prod02.htm (accessed on 20 July 2020).

43. Yu, J.Z.; Chi, H.; Chen, B.H. Comparison of the life tables and predation rates of Harmonia dimidiata (F.) (Coleoptera: Coccinellidae) fed on Aphis gossypii Glover (Hemiptera: Aphididae) at different temperatures. Biol. Control 2013, 64, 1-9. [CrossRef]

44. Chi, H. CONSUME-MSChart: Computer Program for Consumption Rate Analysis Based on the Age Stage, Two-Sex Life Table. 2020. Available online: http://140.120.197.173/Ecology/prod02.htm (accessed on 9 July 2020).

45. Chi, H. TIMING-MSChart: Computer Program for Consumption Rate Analysis Based on the Age Stage, Two-Sex Life Table. 2020. Available online: http://140.120.197.173/Ecology/prod02.htm (accessed on 9 July 2020).

46. Efron, B.; Tibshirani, R.J. An Introduction to the Bootstrap; Chapman and Hall: New York, NY, USA, 1993.

47. Akköprü, E.; Atlıhan, R.; Okut, H.; Chi, H. Demographic assessment of plant cultivar resistance to insect pests: A case study of the dusky-veined walnut aphid (Hemiptera: Callaphididae) on five walnut cultivars. J. Econ. Entomol. 2015, 108, 378-387. [CrossRef] [PubMed]

48. Qiu, B.L.; De Barro, P.J.; Xu, C.X.; Ren, S.X. Effect of temperature on the life history of Encarsia bimaculata (Hymenoptera: Aphelinidae), a parasitoid of Bemisia tabaci (Hemiptera: Aleyrodidae). Eur. J. Entomol. 2006, 103, 787-792. [CrossRef]

49. McClay, A.S.; Hughes, R.B. Temperature and host-plant effects on development and population growth of Mecinus janthinus (Coleoptera: Curculionidae), a biological control agent for invasive Linaria spp. Biol. Control 2007, 40, 405-410. [CrossRef]

50. Liu, S.S. The influence of temperature on the population increase of Myzus persicae and Lipaphis erysimi. Acta Entomol. Sin. 1991, 34, 189-197.

51. Flanders, S.E. Aphelinid biologies with implication for taxonomy. Ann. Entomol. Soc. Am. 1953, 46, 84-94. [CrossRef]

52. Schirmer, S.; Sengonca, C.; Blaeser, P. Influence of abiotic factors on some biological and ecological characteristics of the aphid parasitoid Aphelinus asychis (Hymenoptera: Aphelinidae) parasitizing Aphis gossypii (Sternorrhyncha: Aphididae). Eur. J. Entomol. 2008, 105, 121-129. [CrossRef]

53. Sengonca, C.; Schirmer, S.; Blaeser, P. Life table of the aphid parasitoid Aphelinus asychis (Walker) (Hymenoptera, Aphelinidae) parasitizing different age groups of Aphis gossypii Glover (Homoptera, Aphididae). J. Plant Dis. Protect. 2008, 115, 122-128. [CrossRef]

54. Raney, H.G.; Coles, L.W.; Eikenbary, R.D.; Morrison, R.D.; Starks, K. Host preference, longevity, developmental period and sex ratio of Aphelinus asychis with three sorghum-fed species of aphids held at controlled temperatures. Ann. Entomol. Soc. Am. 1971, 64, 169-176. [CrossRef]

55. Byeon, Y.W.; Tuda, M.; Takagi, M.; Kim, J.H.; Choi, M.Y. Life history parameters and temperature requirements for development of an aphid parasitoid Aphelinus asychis (Hymenoptera: Aphelinidae). Environ. Entomol. 2011, 40, 431-440. [CrossRef] 
56. Kang, E.J.; Byeon, Y.W.; Kim, J.H.; Choi, M.Y.; Choi, Y.S. The effect of temperatures on the biological characteristics of two aphid parasitoids Aphelinus asychis (Walker) and Aphelinus varipes (Forster) (Hymenoptera: Aphelinidae) on two aphid hosts. Korean J. Appl. Entomol. 2012, 51, 397-403. [CrossRef]

57. Jackson, H.B.; Eikenbary, R.D. Bionomics of Aphelinus asychis (Hymenoptera: Eulophidae) an introduced parasite of sorghum greenbug (Homoptera: Aphididae). Ann. Entomol. Soc. Am. 1971, 64, 81-85. [CrossRef]

58. Cate, R.H.; Eikenbary, R.D.; Morrison, R.D. Morrison. Preference for and effect of greenbug parasitism and feeding by Aphelinus asychis. Environ. Entomol. 1977, 6, 547-550. [CrossRef]

59. Bernal, J.; Gonzalez, D. Temperature requirements of 4 parasites of the Russian wheat aphid Diuraphis noxia. Entomol. Exp. Appl. 1993, 69, 173-182. [CrossRef]

60. Wilbert, H. Das Ausleseverfahren von Aphelinus semiflavus Howard und die Abwehrreaktionen seiner Wirte (Hymenoptera, Aphelinidae). Beitr. Entomol. 1964, 14, 159-219.

61. Gerling, D.; Roitberg, B.D.; Mackauer, M. Instar-specific defense of the pea aphid, Acyrthosiphon pisum-Influence on oviposition success of the parasite Aphelinus asychis (Hymenoptera: Aphelinidae). J. Insect Behav. 1990, 3 , 501-514. [CrossRef]

62. Tang, Y.Q.; Yokomi, R.K. Biology of Aphelinus spiraecolae (Hymenoptera: Aphelinidae), a parasitoid of the Spirea aphid (Homoptera: Aphididae). Environ. Entomol. 1996, 25, 519-523. [CrossRef]

63. Byeon, Y.W.; Tuda, M.; Takagi, M.; Kim, J.H.; Kim, Y.H. Non-reproductive host killing caused by Aphelinus asychis (Hymenoptera: Aphelinidae), a parasitoid of cotton aphid, Aphis gossypii (Homoptera: Aphididae). J. Fac. Agric. Kyushu Univ. 2009, 54, 369-372.

64. Chi, H.; Mou, D.F.; Allahyari, H.; Yu, J.Z.; Huang, Y.B.; Yang, T.C.; Farhadi, R.; Gholizadeh, M. Finite predation rate: A novel parameter for the quantitative measurement of predation potential of predator at population level. Nat. Preced. 2011. [CrossRef]

65. Noyes, J.S. Universal Chalcidoidea Databas. 2006. Available online: http://www.nhm.ac.uk/jdsml/researchcuration/projects/chalcidoids/ (accessed on 5 June 2006).

66. Nowierski, R.M.; Fitzgerald, B.C. Supercooling capacity of Eurasian and North American populations of parasitoids of the Russian wheat aphid, Diuraphis noxia. Biocontrol 2002, 47, 279-292. [CrossRef]

67. Kalinkat, G.; Rall, B.C.; Björkman, C.; Niemelä, P. Effects of climate change on the interactions between insect pests and their natural enemies. Clim. Chang. Insect Pests 2015, 119-135.

68. Angilletta, M.J. Thermal Adaptation: A Theoretical and Empirical Synthesis; Oxford University Press: Oxford, UK, 2009.

69. Abram, P.K.; Boivin, G.; Moiroux, J.; Brodeur, J. Behavioural effects of temperature on ectothermic animals: Unifying thermal physiology and behavioural plasticity. Biol. Rev. 2016, 92, 1859-1876. [CrossRef] [PubMed]

70. Sánchez-Guillén, R.A.; Córdoba-Aguilar, A.; Hansson, B.; Ott, J.; Wellenreuther, M. Evolutionary consequences of climate-induced range shifts in insects. Biol. Rev. 2016, 91, 1050-1064. [CrossRef] [PubMed]

71. Córdoba-Aguilar, A.; González-Tokman, D.; González-Santoyo, I. Insect Behavior: From Mechanisms to Ecological and Evolutionary Consequences; Oxford University Press: Oxford, UK, 2018.

(C) 2020 by the authors. Licensee MDPI, Basel, Switzerland. This article is an open access article distributed under the terms and conditions of the Creative Commons Attribution (CC BY) license (http://creativecommons.org/licenses/by/4.0/). 